\title{
Cytochrome-b の波形異常を認めた
}

\section{慢性肉芽腫症 (CGD) の一男児例}

\author{
小林一郎・有 賀 正* ・上野範 博*・石 坂 明 人 $^{*}$ \\ 高橋豊* ・渡辺 徹* ・崎山幸雄*・松本脩三* \\ 坂根郁夫**・高山 大**・高橋和 彦**・小山次郎** \\ 由 利賢次・福島直樹
}

\section{Spectrally abnormal cytochrome-b in a male patient with chronic granulomatous disease}

\begin{abstract}
Ichiro Kobayashi, Tadashi Ariga*, Norihiro Ueno*, Akihito Ishizaka*, Yutaka Takahashi*, Toru Watanabe*, Yukio Sakiyama*, Shuzo Matsumoto*, Fumio Sakane**, Hajime Takayama**, Kazuhiko Takahashi**, Jiro Koyama**, Kenji Yuri and Naoki Fukushima
\end{abstract}

Department of Pediatrics, Oji General Hospital. Tomakomai* Department of Pediatrics, Hokkaido University, School of Medicine** Department of Hygenic Chemistry, Hokkaido University, Faculty of Pharma ceutical Science

\section{【Summary】}

Cytochrome-b and flavin adenine dinucleotide (FAD) were measured in neutrophils from a male patient and his family with the X-linked form of Chronic Granulomatous Disease (CGD). The membrane fraction of the patient's neutrophils contained $93 \mathrm{pmol} / \mathrm{mg}$ protein of $\mathrm{FAD}$ (control $102 \pm 20$, mean $\pm \mathrm{sd}$ ), and $32 \mathrm{pmol} / \mathrm{mg}$ protein of cytochrome-b (control $88 \pm 20$, mean \pm sd). In the spectrophotometric study, the maximal absorbance peak of cytochrome-b was at $421 \mathrm{~nm}$, as that from control was at $427 \mathrm{~nm}$. Cytochrome-b in neutrophils from his mother and a sister, who were thought to be carriers, had their maximal absorbance peak at $425 \mathrm{~nm}$. These findings suggest that the spectral abnormality of cytochrome-b contribute to the pathogenesis of CGD in this case.

Key words : granulomatous disease. chronic, $\mathrm{NADPH}$-dependent $\mathrm{O}^{-}$-generating oxidase, cytochrome-b, spectral abnormality 


\section{【概【要】}

伴性劣性遗伝形式をとる慢性肉芽腫症の一男児例およびその家族の末梢血好中球より，その膜分画にある cytochrome-bおよび flavin adenine dinucleotide (FAD) を測定した. FAD は対照 $102 \pm 20 \mathrm{pmol} / \mathrm{mg}$ protein, 患児 $93 \mathrm{pmol} /$ $\mathrm{mg}$ pratein, 母親 $84 \mathrm{pmol} / \mathrm{mg}$ protein, 長女 $102 \mathrm{pmol} / \mathrm{mg}$ protein, 次女 $96 \mathrm{pmol} / \mathrm{mg}$ protein であった. cytochrome·b 㤌対照 $88 \pm 20 \mathrm{pmol} / \mathrm{mg}$ protein, 患児 $32 \mathrm{pmol} / \mathrm{mg}$ protein, 母親 $57 \mathrm{pmol} / \mathrm{mg}$ protein, 長女 $98 \mathrm{pmol} / \mathrm{mg}$ protein, 次女 $81 \mathrm{pmol} / \mathrm{mg}$ protein であった. dithionite を用いた還元一酸化差スペクトルの $r$-band は, 対照 427 $\mathrm{nm}$, 患児 $421 \mathrm{~nm}$ と, 患児で短波長側に偏位していた. 保因者と考えられた母親, 次女の $r$-band は $425 \mathrm{~nm}$ に存在 していた.

以上より本症例の病態に, cy tochrome-b の構造的ないし量的異常が関与している可能性が示唆された.

慢性肉芽腫症（以下 CGD と略す）は好中球の活性酸 素産生障害に基つくく殺菌能の異常により生ずるとされて いる.その機序はいまだ不明の点が多いが, cytochromeb (以下 Cyt-b と略す) の久損例の報告以来, NADPH 传存 $\mathrm{O}_{2}{ }^{-}$産生䤃素の component と考えられているCytb や flavoprotein の異常が注目されている1,2).

今回われわれは伴性劣性遺伝形式をとる CGD の一男 児例とその家族の末梢血好中球膜分画の Cyt-b および flavin adenine dinucleotide (以下 FAD と略す)につ いて検討し, 本症例の病態に Cyt-b の構造異常が関与し ている可能性を示晙する結果を得たので報告する.

\section{I. 症 例}

1 歳男児. 生後 5 力月で頸部膿瑒罹患後, 口内炎, 中 耳炎，皮膚膿瘍を反復している，家族歴では母親に頸部 リンパ節切除，次女に頸部リンパ節結核の既往がある. また，母親の弟 2 人および従兄 2 人が幼児期に死亡して いるが詳細は不明である（図 1 ).

好中球機能検查では, 細菌領食能は正常, 殺菌能は著 明に低下していた。 lipopolysaccharide (LPS) 刺激によ る nitroblue tetrazolium (NBT) slide test において は, 対照 $89 \%$, 患児 $0 \%$, 母親 $65 \%$, 長女 $95 \%$, 次
女 58\% であった。 zymozan 刺激による全血法 chemiluminescence では対照 $169 \times 10^{3}$ c.p.m, 患児 0 c.p.m, 母 親 $87 \times 10^{3}$ c.p.m, 長女 $141 \times 10^{3}$ c.p.m, 次女 $53 \times 10^{3}$ c.p.m であった.

以上より本症例は伴性劣性遗伝形式をとる CGD と診 断された。

\section{II. 方 法}

\section{1） Cyt-b の測定}

末梢血上り分離した好中球を $20 \mathrm{mM}$ Tris $\mathrm{HCl}$ 緩衝 液 $\mathrm{PH} 7.4,0.34 \mathrm{M}$ ショ糖の混合液中に浮遊させ, $2 \mathrm{mM}$ diisopropyl fluorophosphate を加えて sonicateした後, $550 \times \mathrm{g}, 10$ 分間遠心して上清を得た. この上清に過量の dithionite を加え, 還元一酸化差スペクトルをとり，そ の $\alpha$-band $559 \mathrm{~nm}$ の高さをもって測定した $(\Delta \varepsilon=21.6$ $\left.\mathrm{mM}^{-1} \mathrm{Cm}^{-1}\right)$. 測定には島津の UV-300 を用いた。

2) FAD の測定

(1) $r$ 上清を $90^{\circ} \mathrm{C}$ で 5 分間加熱した後, $15,000 \times \mathrm{g}$ で 遠心し，その上清を PH 2.8 として日立分光螢光光度計 650-40を用いて測定した

3）総蛋白濃度の測定

Bio-Rad Laboratories $の$ protein assay reagent

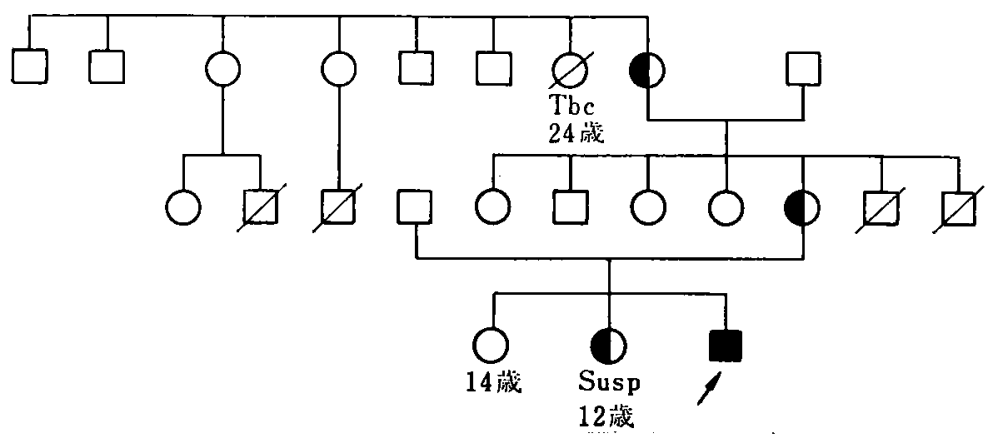

図 1 家系図 
表 1 CGD 家系における Cyt-b. FAD.

\begin{tabular}{lcc}
\hline & $\begin{array}{c}\text { Cytochrome-b } \\
(\text { Pmol/mg protein })\end{array}$ & $\begin{array}{c}\text { FAD } \\
\text { (Pmol/mg protein })\end{array}$ \\
\hline Control & $\mathbf{8 8} \pm 20$ & $102 \pm 20$ \\
Patient & 32 & 93 \\
Mother & 57 & 84 \\
Sister I & 98 & 102 \\
Sister II & 81 & 96 \\
\hline
\end{tabular}

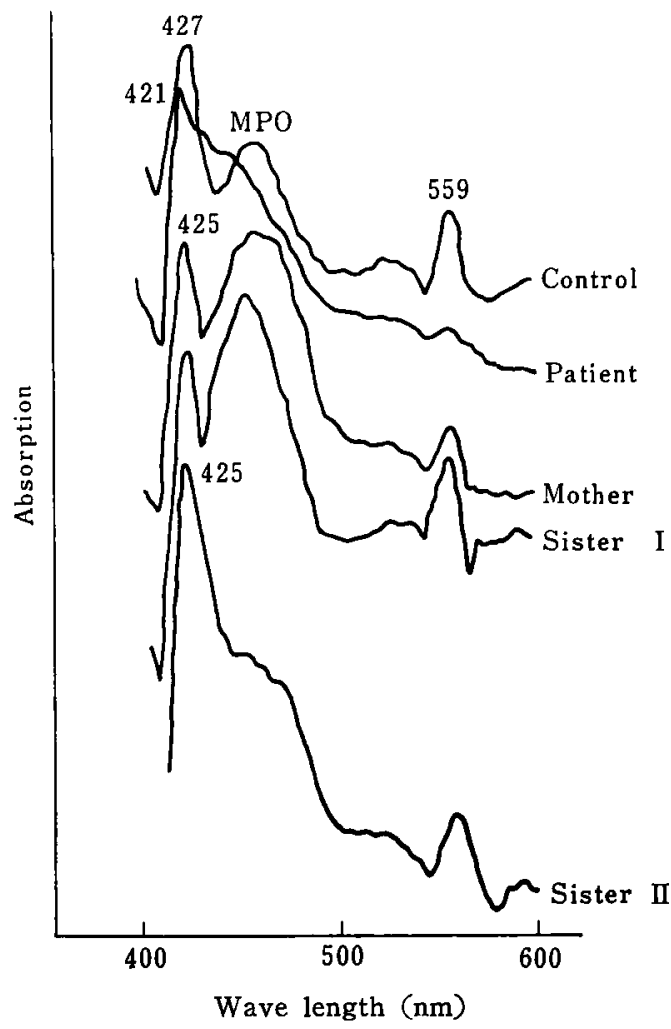

図 2 cytochrome-b の還元一酸化差スペクトル 用いて測定した。

\section{III. 結 果}

Cyt-b は，対照 $88 \pm 20 \mathrm{pmol} / \mathrm{mg}$ protein，患児 32 $\mathrm{pmol} / \mathrm{mg}$ protein，母親 $57 \mathrm{pmol} / \mathrm{mg}$ protein と，患児， 母親で低下していた．長女，次女の Cyt-b 量は正常範囲
内であった（表 1 ）。

Cyt-b のスペクトルを検討すると， $\gamma$-band が対照 427 $\mathrm{nm}$ であったのに対し，患児 $421 \mathrm{~nm}$ と短波長側に偏位 していた。 また，母親，次女の $r$-band は $425 \mathrm{~nm}$ と， 患児と対照の中間に存在していた，長女のそれは 427 $\mathrm{nm}$ であった（図 2).

好酸球增多をを伴ら対照より得られた検体において は，差スペクトルの偏位は認められなかった（データは 省略)。

\section{IV. 考察}

本症例は既往歴, NBT test, Chemiluminescence の 結果より伴性劣性遺伝形式をとる CGD と䛦断され，母 親と次女はその保因者と考えられた。

CGD に扔ける NADPH 估存 $\mathrm{O}_{2}^{-}$産生酵素の異常に関 しては，伴性遺伝型においては Cyt-bが久損し，常染色 体性遺伝型においては Cyt-b の機能異常が考えられると する報告4)，Cyt-bよりは flavoprotein の異常が主因で あるとする報告がある゙

本症例では FAD は正常量存在し, Cyt-b は低下して いた.さらに Cyt-b の差スペクトルにおいては $\gamma$-band が $421 \mathrm{~nm}$ と短波長側に偏位していた。 また，保因者と 考えられた母親および次女においては，患児と対照の中 間に存在していた，CGD における Cyt-b の波形異常に ついては，436n と長波長側に $r$-band をもち，量的 に低值を示す症例が報告されている6 。本症例に拈いて は短波長側への偏位であり，好酸球による影響も考虑さ れたが，好酸球増多を伴う対照の検討では，その影響は 認められなかった。

これらのことより本症例では，Cyt-b の分光学的偏位 より何らかの構造上の異常が，量的低下と共に存在して いる可能性も示唆された。

現在のところ Cyt-b, flavoprotein のいずれむ活性を 有する純粋な形で単離されていない，今後，単離された Cyt-b あるいは flavoprotein による構造および機能異常 の解析が必要上考えられる，なお，この症例で示された 異常が伴性劣性遗伝形式をとる CGD で広く認められる か否かに関しては，他の家族例について現在検討中であ る.

1) Gallin, J.I., Beuscher, E.S., Selingmann, B.E., Nath, J., Geither, T., Katz, P. : Recent Advantages in Granulomatous Disease. Ann. In- tern. Med., 99 : 657 674, 1993.

2) Segal, A.W., Jones, O.T.G., Webster, D., Allison, A.C. : Absence of a newly described 
cytochrome-b from neutrophils of patient with Chronic Granulomatous Disease. Lancet, 2 : 446 449, 1978.

3) Sakane, F., Takahashi, K., Koyama, J. : Purification and characterization of a membranebound NADPH-cytochrome $c$ reductase capab le of catalyzing menadione-dependent $\mathrm{O}_{2}$ - formation in Guinea Pig polymorphonuclear leukocyte. J. Biochem., $96: 671 \sim 678,1984$.

4) Segal, A.W., Cross, A.R., Garcia, R.C., Borregard, N., Valerius, N.H., Soothhill, J.F., Jones, O.T.G. : Absence of Cytochrome b-245 in Chronic Granulomatous Disease. N. Engl. J. Med., 308: 245 251, 1983.

5) Gabig, T.G., Lefker, B.A. : Deficient Flavoprotein component of the NADPH-dependent $\mathrm{O}_{2}{ }^{-}$-generating oxidase in the Neutrophils from three male patients with Chronic Granulomatous Disease. J. Clin. Invest., $73: 701 \sim$ $705,1984$.

6) Gabig, T.G.: The NADPH-dependent $\mathrm{O}_{2}-$ generating oxidase from Human Neutrophils. J. Biol. Chem., $258: 6352 \sim 6356,1983$. 